Journal of Tourism Theory and Research

Online, http://dergipark.gov.tr/jttr

Volume: 5(3), 2019

\title{
The mediation role of academic procrastination on the effect of the university stu- dents' long-term orientation to career intention in the tourism industry
}

\author{
Mahmut Baltacı ${ }^{1}$, A.Celil Çakıı'², Beril Dönmez ${ }^{3}$
}

\begin{abstract}
Individuals who are trained at university level are expected to work in appropriate jobs for their education. In this direction, a research has been carried out to determine the mediating role of academic procrastination behaviours under the influence of tourism education students' career intentions in tourism. In the descriptive study, the data were compiled with a questionnaire based on the literature. The universe of the research consists of undergraduate and graduate students in Turkey. The target population of the research consists of the students who reregister in the fall semester of 2016-2017 academic year for the Tourism Management program of the Faculty of Tourism and Tourism and Hotel Management program for the Vocational School of Tourism of the two public universities. The questionnaire was applied face-to-face between November 23, December 5, 2016, using the convenience sampling technique. The data of 462 questionnaires were subjected to factor analysis and stepwise regression analysis as well as descriptive statistics. It was determined that $9.3 \%$ of the planning and diligence can explain career intention in tourism. In addition, it was found that diligence was a partial mediator. The study concludes with the suggestion that students who want to pursue a career in tourism sector should achieve this not only with their planning but also with their diligence.
\end{abstract}

Keywords: Long Term Orientation, Academic Procrastination, Career Intention, Tourism

\author{
Received Date :08.04.2019 \\ Accepted Date : :01.07.2019
}

To cite this article: Baltacı, M., Çakıcı, A.C., Dönmez, B. (2019). The mediation role of academic procrastination on the effect of the university students' long-term orientation to career intention in the tourism industry. Journal of Tourism Theory and Research, 5(3), 340-354.

\footnotetext{
${ }^{1}$ Lecturer, Selçuk University, mbaltaci@selcuk.edu.tr

${ }^{2}$ Prof. Dr., Mersin University, celilcakici@mersin.edu.tr

${ }^{3}$ Asist Prof. Dr., Mersin University, berildonmez@mersin.edu.tr 


\section{Introduction}

The university departments providing tourism education are on a continous increase. Although some of the university level tourism students have chosen to continue their careers in the tourism sector, others decide not to work in this sector for various reasons while they actually continue their education, during their internship or after graduation. While the interesting, exciting and valuable character of the sector have been found to have a positive effect on students' preference of a career in the sector (Kuşluvan \& Kuşluvan, 2000: 257), on the other hand reasons like seasonality of tourism, insignificance of qualified personnel, non-institutionalization of the businesses, job stress, irregular working hours, ever-decreasing real wage levels, person-sector alignment, promotion possibilities, problems of work-family conflict can be counted among the reasons that has a negative effect (Akin \& Köksal, 2005: 443; Akyol \& Zengin, 2012; Yanardağ \& Avc1, 2012: 39; Kozak, 2005; Duman, Tepeci \& Unur, 2006:65; Kuşluvan \& Kuşluvan, 2000: 257).

Whether the students' view the events in tourism sector in short-term and/or long-term affects their career development. One of the cultural dimensions of Hofstede's cultural values (Hofstede \& Minkov, 2010: 493) is the long-term orientation that allows us to see time in a holistic way and to value the past and the future. Therefore, students can only adopt the traditions and work for future benefits in a long-term perspective (Bearden, Money \& Levins, 2006: 457). The success of the students who are educated in tourism can be related to their academic activities. In this context, the term "academic procrastination" may be associated with the students' long-term orientations and career interests. Rothbulum et al. (1986) considered the academic procrastination as always or almost always delaying the academic tasks in hand and always or almost always feeling anxious about it at an uncomfortable level. The behaviors such as not performing academic tasks timely and leaving them to the last minute are very important problems since how frequent they are among stu-

Copyright (C) 2015 by JTTR dents. Individuals may have many reasons for academic procrastination behavior, such as inability to manage time, perfectionism or fear from failure.

In this study, the long-term orientations and career interests of associate degree (two-years) and undergraduate (four-years) students studying tourism management are discussed. In addition, the mediative role of academic procrastination between the long-term orientation of students and their career interests is also examined.

\section{Literature review}

The long-term orientation has been handled by many authors within the individual and social dimensions. From a social perspective, some cultures are open to long-term approaches and expectations, while some others give more importance to the short-term approach (Ermurat, 2013: 54). Long-term orientation is a salient aspect of cultural values of some nations and is considered to have an impact on consumer decision-making processes (Bearden, Money, Levins, 2006: 456). Long-term orientation is the fifth dimension added by Hofstede after the original four cultural dimensions that attempt to differentiate between eastern and western cultures. Other cultural dimensions of Hofstede are "power distance", "uncertainty avoidance", "individualism versus collectivism" and "masculinity versus femininity" (Öğüt \& Kocabacak, 2007: 150-155; Sofyalıoğlı \& Aktaş, 2001: 90).

The long-term orientation is explained as the tendency towards long-range purposes and prioritize the actualisation of ideas that have a effect on the events after a long period of time (Lumpkin et al., 2010: 241). Hofstede describes the long-term orientation as opposed to the short-term orientation and positively correlates the long-term orientation with the future orientation (Lumpkin et al., 2010: 242). According to Hofstede (1991), longterm orientation is a culture of positivity, dynamism and future-orientation. It is associated with four positive Confucian values: "persistence (perseverance)", 'ordering relationships by status and 
observing this order", "thrift" and "having a sense of shame'. (Fang, 2003: 48). Short-term orientation, however, represents a negative, static, traditional and past-oriented culture associated with four negative Confucian values: "personal steadiness and stability", "protecting your face", "respect for tradition" and "reciprocation of greetings, favors and gifts" (Fang, 2003: 348).

Bearden, Money and Nevins (2006), tried to assess the development and determine the validity of long-term orientation. They applied the questionnaire which includes 8 items which reflect the tradition and planning angle of long term orientation to more than 2000 participants. Intracultural and intercultural individual differences of longterm orientation were found.

Nevins, Bearden and Money (2007) examined the relationships between ethical values, conservation of natural life, business ethics, long-term orientation, respect for customs and planning. In two American universities, they applied a questionnaire which included 8 items to 292 college students. Among the sample, $49 \%$ were female and $95 \%$ of students were working at least part-time. It has been found that long-term orientated students who are more devoted to planning and traditions attach more importance to ethical values.

Long term orientations of students may be related to what they think about a career. Career; in terms of internal factors, is the tendency to selfrealization by specifying the direction and the path appropriate to the personality of the individual (Unur, Duman and Tepeci, 2004: 395). The concept of career, which is not exactly corresponded with a Turkish word, is generally used to describe progress and the upward movement in hierarchy and is defined as the activity, responsibility, attitude and behavior development of the individual in the work life (Sümer, 2016). Based on this definition, the career interest can be defined as being inclined towards the development of this attitude and behavior and having a desire to make a career.

Kuşluvan and Kuşluvan (2000) measured the attitudes of tourism students towards working in the tourism sector. They applied the questionnaire which included 91 items to 397 students. It was found that the students were less willing to pursue careers and did not want to continue their studies in the tourism sector after graduation. In many respects, students evaluated the tourism sector negatively. In the studies conducted by Kozak and Kizilırmak (2001) and Duman, Tepeci and Unur (2006) it is found out that students who did internship are more negative towards tourism sector compared to students who didn't do internship and seasonality has found to have an important place in this negative attitude. Richardson (2009) also found that students are negative towards career goals in the tourism sector. Yildiz (2013) has shown that the negative thoughts towards working in the sector have increased as it passes to the upper classes among the students receiving tourism education.

Although most of the students develop a negative attitude towards tourism sector, you can see some positive attitudes from the students in some studies. For example; Türkay and Solmaz (2011), found the career interest of the students in tourism sector to be positive in their research conducted among the students received tourism education at high school, associate, undergraduate and graduate level. Baltacı, Üngüren, Avsallı and Demirel (2012) found that students who willingly prefer to study in the department are more willing to pursue a career in their field of study. Dinçer, Akova and Kaya (2013) found that students who are educated at associate degree level want to continue their careers in tourism sector and aim to be in top positions in the long term.

In addition to the studies in which positive or negative attitudes of the students have been investigated, the presence of students who are confused or indecisive are also determined. Guzel, Akdag, Guler and Sener (2014) measured tourism perceptions of students studying tourism in Çanakkale, Mersin and Cyprus. Students from three different universities were found to be indecisive in their career interests.

Roney and Öztimur (2007), aimed at measuring perceptions of career in the tourism sector among the tourism students of three different uni- 
versities in Turkey. They applied the questionnaire composed of 12 items to 450 students. Students' perceptions of career were neither positive nor negative. Willingness to be in the field; the desire to work in the tourism sector after graduation and work experience were found to be important factors in shaping an image of a career in tourism.

Another variable that may be associated with the long-term orientation of the students receiving tourism education is the academic procrastination. Academic procrastination is pointlessly delaying the academic tasks in hand and being uncomfortable with the situation (Solomon and Rothblum, 1984: 503). Academic procrastination is a common event in the lives of the university students (Blunt and Pychyl 1998: 837).

Solomon and Rothblum (1984) aimed to determine the frequency of academic procrastination of university-level students and the reasons for this procrastination behavior. Among the reasons for the academic procrastination are the fear of failure and work avoidance. Academic procrastination was not only a deficiency in time management or study habits, but also a complex construct that comprises behavioral, cognitive and affective components.

Ferrari (1991) compared the students who received associate degree education and those who did not. Two separate samples were studied and the first sample consisted of 241 students and the second sample included 287 students. Since there were no male students, a questionnaire including Mann's (1982) decision-making delay scale and Lay's (1986) behavioral delay scale was applied to the female students who participated in psychology classes. Based on these two independent studies, women found to procrastinate and anxiously avoid evaluation especially in the presence of audience. These avoidance tendencies appear to have a motivational basis since there is no significant difference in the cognitive thinking skills. These results support the clinical similarities of Burka and Yuen (1983), suggesting that the procrastination is based on low self-confidence and high self-doubt.
Ferrari, Parker and Ware (1992) examined the relationship between the students' academic procrastination, self-efficacy and locus of control via the Myers-Briggs Personality Scale. Students have been found to be prone to academic procrastination. Blunt and Pychyl (1998) examined the relationship between orientation status, tendency to boredom and academic procrastination. A positive relationship between decision-making and statusbased hesitation and a definite relationship between the tendency to be bored, state orientation and procrastination were found.

Onwuegbuzie (2004) examined the prevalence of procrastination among the graduate students, and the relationship between academic procrastination and six dimensions of statistics anxiety. A questionnaire consisting of 51 items of statistics anxiety rating scale and 26 items of student procrastination rating scale were applied to 135 graduate students enrolled in the education research course. It has been found that procrastination is mostly about writing term papers, studying for exams and completing weekly reading assignments. In addition, it was found that the academic procrastination was due to the fear of failing the course and worth of statistics, interpretation anxiety, test and class anxiety, computational self-concept, fear of asking for help and fear of teachers. Howell and Watson (2007) investigated the relationships between procrastination, achievement goal orientations and learning strategies among undergraduate students. Procrastination was found to be related negatively to a mastery-approach goal orientation and positively to a mastery-avoidance goal orientation. Procrastination was also found to be related to greater disorganization and less use of cognitive and meta-cognitive strategies and it is revealed that disorganization and the use of cognitive strategies were most predictive of procrastination.

Klassen, Krawchuk and Rajani (2007) conducted two researches investigating the academic procrastination and 456 undergraduate students received a 16-item procrastination scale, a 12-item self-regulation scale, and a 10-item self-esteem scale. In the first research, the relationships among 
academic procrastination, self-regulation, academic self-efficacy, self-esteem, and self-efficacy for self-regulation was examined. The results reveal that although other self-variables are related to procrastination, self-efficacy for self-regulation is highly predictive of procrastination tendencies. In the second study, the authors examined the academic and motivation characteristics of "negative procrastinators," the undergraduates who are most adversely influenced by procrastination. In this study with 195 participants who were classified as negative procrastinators found to have significantly lower GPAs, higher levels of daily and task procrastination, lower predicted and actual class grades, and lower self-efficacy for self-regulation. Ferrari, Özer and Demir (2009) examined the prevalence of chronic procrastination as a function of demographic variables. Ferrari et al. (2005) found that chronic procrastination was divided into three types. These are; decisional (inability to make a decision within a specified time period); arousal (purposefully waiting until the last minute for a thrill-seeking sensation, yielding pleasure from "beating the clock"); and avoidance (delayed motivation by a desire to prevent performance evaluation and fears).

Within the scope of the survey conducted in 2009, 354 participants were presented with a 5item Decisional Procrastination scale, 15-item Adult Inventory of Procrastination scale, and a 20item General Procrastination scale. As a result of the study, it was found that $17.5 \%$ of the participants were indecisive procrastinators, $13.8 \%$ were avoidant procrastinators, and $14.7 \%$ were arousal procrastinators. Results did not yield significant differences for gender or age on any types of procrastination, which is consistent with other international samples. However, significant differences emerged depending on the number of children such that Turkish adults who had more than three children claimed to be more indecisive rather than arousal or avoidant procrastinators. Respondents with less than a graduate degree reported higher rates of indecision than did respondents with at least a graduate degree. Jadidi, Mohammadkhani and Tajrishi (2011) examined the relationships between perfectionism and academic procrastination among the students of Tehran University. It was found that students with higher scores in perfectionism scale revealed more academic procrastination in comparison with individuals with lower scores in the same scale.

\section{Research methodology}

\subsection{Purpose of the research}

Career goals are very important for college-educated individuals. Career interests may vary according to the individual. Some of these individuals are students whose career goals are greater due to their long-term orientation. Students often fall in a tendency to academic procrastination throughout their education. These delays are sometimes related to their goal of success, others are arbitrary academic delays. The aim of this research is to determine whether the long-term orientations of university-level tourism students influence their career interests in tourism. However, it was aimed to determine whether the academic procrastination has a meditative role between their career interest and their long-term orientations.

\subsection{Hypotheses of the research}

Tourism is a sector that can be affected rapidly by many factors over time. Being a labor-intensive sector, employing qualified personnel in the sector is very important for sustainability. The desire to make a career in the tourism sector is extremely important especially in terms of students who are studying tourism. The career goals that started in the first years of student life display themselves at the highest level after graduation. Dinçer, Akova and Kaya (2013) have shown that students are willing to be in the tourism sector in the long run. In addition, it has been determined that those who prefer tourism programs willingly intend to make a career in the sector (Baltac1, Üngüren, Avsallı and Demirel, 2012). Successful planning and a bright future are positively related. (Brigham, Lumpkin, Payne \& Zachary, 2014). For this reason, since tourism students aim for a bright career in the tourism sector, the following hypothesis can be written, assuming that their long-term orientations may affect their tendency towards making a career in tourism sector. 
$H_{1}$ : The long-term orientation of universitylevel tourism students influences their career interest in the tourism sector.

Long-term orientation is a process that sometimes requires a lot of patience for the individual. While students want to achieve success in a short period of time during the training period, they need to capture this success in the long term. In some course's success can be measured in the short term, while some courses it can be measured in the long term. Judith, Kenneth, John, Suzanne, and Andrew (2000) found that students were motivated by short term psychology lectures, enjoying the course and complete it successfully. Long term students often tend to procrastinate by postponing their work to another time in order to achieve their long-term goals (Solomon and Rothblum, 1984: 503). One of the reasons for this is the tendency to aim for perfection, that is, taking a higher grade. Jadidi, Mohammadkhani and Tajrishi (2011) found that students studying at the University of Tehran often resort to academic procrastination in defending perfectionism. The studies show that students aim for perfection and set out their success goals in the long term. The following hypothesis has been established in the light of these studies.

$\mathrm{H}_{2}$ : The long-term orientation of universitylevel tourism students has an effect on the tendency towards academic procrastination.

Academic procrastination is unnecessarily post ponding what is to be done to another time and feeling uncomfortable about it (Solomon and Rothblum, 1984: 503). As can be understood from this definition, academic procrastination is very common and it is inevitable that the university students procrastinate. In a study (Jadidi, Mohammadkhani and Tajrishi, 2011), the relationship between students' perfectionism and academic procrastination behavior was investigated. Students with higher grades were found to be involved more in academic procrastination than those who received lower grades because of their perfectionism. Students who procrastinate sometimes postpone what is to be done arbitrarily, sometimes because of perfectionism.
Career interest is something that students think about before they graduate. Every human being who is trained wants to work and succeed in the field of expertise in which they are trained. Türkay and Solmaz (2011) aimed to measure the effect of career values and leadership skills of tourism students on their desire to have a career in tourism. 287 students took the 27-item scale and the "managerial competence" in leadership skills was found to be prominent. And this leadership skills are proved to have an indirect positive effect on the desire to make a career in tourism. Students may be more willing to pursue career goals when they procrastinate in the name of perfection and thinking that they will achieve success as a result of perfectionism. For this reason, the following hypothesis has been established.

$H_{3}$ : Academic procrastination behaviors of university students receiving tourism education affect their career interests.

The students who are studying tourism at university level naturally aim for a career in tourism after graduation (Dinçer, Akova and Kaya 2013, Baltac1, Üngüren, Avsallı and Demirel, 2012). Students procrastinate throughout their education in order to be more successful and to maintain a perfect academic life. (Jadidi, Mohammadkhani and Tajrishi, 2011). The following hypothesis has been established in view of the assumption that the academic procrastination plays a mediating role between the long-term orientation of university students receiving tourism education and their career interests in the sector.

$\mathrm{H}_{4}$ : Academic procrastination plays a mediatory role in the relationship between long-term orientations and career interests of university students receiving tourism education.

\subsection{Research design and data collection method}

The population of the study consists of the undergraduate and graduate level students studying tourism in Turkey. Target population of the study consists of the students who re-registered to the Tourism Management Departments of Tourism Faculty which is found in one of the two public universities where this research was conducted and the Tourism and Hotel Management programs 
of the two vocational schools found in those universities in the fall semester of 2016-2017 academic year. Due to the fact that the exact number of tourism students cannot be obtained, it is aimed to reach 384 students for practical reasons. Although the exact size of the universe is unknown, it is stated that this number will be enough if the size of the universe is over 100.000 by Sekaran (2003: 294). It was decided to go beyond the sample size considering that there might be some missing or incorrect observation. In November of 2016, a total of 464 valid surveys were conducted with drop-off/pick-up and face-to-face methods.

The research was designed in the form of descriptive and relational search model and the data were compiled using a questionnaire which is developed on the basis of the literature. In addition to questions about the demographics and education of students in the questionnaire, there are also 8 -item long-term orientation, 10 -item career interest in tourism and 19-item academic procrastination scales.

The long-term orientation scale was developed by Bearden, Money and Nevins (2006). The scale is two-dimensional consisting of traditionalism and planning, accounting for $55.05 \%$ of the total variance. Career interests scale was developed by Riegel and Dallas (1998) and Kuşluvan and Kuşluvan (2000). The scale is also two-dimensional and accounts for $44 \%$ of the total variance. Academic procrastination scale was developed by Çakıcı (2003). The scale has five dimensions and accounts for $54.38 \%$ of the total variance. The response categories for all the items in the scales were subjected to a 5-point Likert scale of 1: strongly disagree, ... 5: strongly agree.

Missing data analysis was applied to the scales; the analysis has shown that the lost data rate varies between $0.2 \%$ and $5.4 \%$. Since it was determined that the missing data have been lost randomly, the average of the relevant items has been assigned to their place. Then, multivariate analysis was applied in reference to scales and; two observations were removed from the data sets.

Whether the data obtained from the scales were multivariate normal distributions or not were tested separately. In this direction, the binary correlation between sequential Mahalanobis values and chin for each scale was checked to see if the number of items pertaining to the scale was greater than the theoretical values at the $5 \%$ significance level. The correlation value calculated for the 8item long-term orientation scale was 0.975 ; theoretical value of 0.841 . The correlation for the $10-$ item career interest scale was 0.988 ; the theoretical value of 0,860 . The correlation coefficient for the 19-item academic procrastination scale was calculated as 0,986 ; the theoretical value was 0.909 . Since the number of items of correlation coefficients calculated for each of the three scales was found to be greater than the theoretical values at the significance level of $0.5 \%$, the data obtained from each of the three scales were concluded as multivariate normal distributions (Kalayci, 2016: 216). Factor and regression analyses were used as well as descriptive statistics.

The service orientations of the students were determined by the 5-item scale developed by Gwinner et al. (2005). The original English scales were translated into Turkish by the researchers under the supervision of an English instructor. Then, it was translated from Turkish back to English by another English instructor. There wasn't any problematic difference between the original and the second translation. It is stated that this scale is onedimensional and explains $55.05 \%$ of the total variance. One-dimensionality was also confirmed in our study and $55.7 \%$ of total variance is explained.

Factor analysis was used in the study to ensure the construct validity of the study. Additionally the data obtained from the scales has been examined for the reliability analysis by bisection of the scale except the service orientation subscale, random bisection of the sample and assessment of Cronbach Alpha values for singular and plural digit items. Item-total correlations and multiple explanatory variables (multiple $\mathrm{R}^{2}$ ) has also been calculated. The anticipation was that item-total correlations being positive and greater than +250 (Kalayc1, 2010: 412) and multiple $\mathrm{R}^{2}$ values approaching +1 and not being less that 0.250 while varying between 0 and +1 (Alpar, 2012: 391; Kalayc1, 2008; 412). If the item-total correlation 
variable of an item is too low, the necessity of exclusion from the scale would be considered (Özdamar, 2011: 610; Alpar, 2012: 489).

The reliability coefficient of the extraversion scale was reported to be 0.79 (Tabak, Bask1, Tatar and Çetin, 2010: 545) and the service orientation scale is 0.770 (Gwinner et al. 2005: 139). Table 1 shows the results of the reliability analysis. The reliability coefficients of the two scales were 0.789 and 0.791 , respectively. The item-total correlations were between 0.202 and 0.601 for the extroversion scale and between 0.552 and 0.602 for the service orientation scale; there were no negative signs on both scales. The multiple $\mathrm{R}^{2}$ value of an item of extraversion is $18.5 \%$. Since the itemtotal correlation of this item was 0.3336 , no deletion was performed. After these evaluations, it was concluded that both scales were reliable (Büyüköztürk, 2007; 171).
The 8-item long-term orientation scale was developed by Bearden, Money and Nevins (2006). Turkish adaptation of this scale was done by an English instructor. In our study, 3 items were excluded from the scale, two dimensions were detected and it is determined that $71 \%$ of the total variance was explained. The reliability coefficient of the long-term orientation scale was reported as .82 (Bearden et al., 2006: 461). In the reliability analysis of the 8-item long-term orientation scale, three items ("I make long-term plans (0.202), "The family inheritance is important for me" (0.098) and "I care about staying connected to my past" (0.163).) were decided to be removed from the scale. The multiple $\mathrm{R}^{2}$ value of an item was 0.269 and it was decided to be kept in the scale. The reliability coefficient of the remaining 5 items as a whole was 0.741

Table 1. Reliability coefficients of the scale

\begin{tabular}{|l|c|c|c|}
\hline Coefficients & $\begin{array}{c}\text { Song Term Ori- } \\
\text { entation (LTO) }\end{array}$ & $\begin{array}{c}\text { Career Interest } \\
\text { (CI) }\end{array}$ & $\begin{array}{c}\text { Academic Pro- } \\
\text { crastination } \\
\text { (AP) }\end{array}$ \\
\hline Number of items & 5 & 8 & 19 \\
\hline Alpha coefficient for the first half of the scale & - & 0,822 & 0,746 \\
\hline Alpha coefficient for the second half of the scale & - & 0,743 & 0,776 \\
\hline Alpha coefficient for the odd numbered items & - & 0,737 & 0,753 \\
\hline Alpha coefficient for the even numbered items & - & 0,727 & 0,792 \\
\hline Alpha coefficient for the random selected 234 surveys & 0,761 & 0,834 & 0,842 \\
\hline Alpha coefficient for the random selected 228 surveys & 0,719 & 0,883 & 0,876 \\
\hline Smallest and largest item-total correlation values & $0,428-0,555$ & $0,435-0,747$ & $0,326-0,686$ \\
\hline Negative item-total correlation values & None & None & None \\
\hline Smallest and largest multiple $R^{2}$ values & $0,269-0,457$ & $0,243-0,649$ & $0,268-0,560$ \\
\hline Smallest and largest Alpha value when the item is deleted & $0,676-0,729$ & $0,829-0,864$ & $0,843-0,858$ \\
\hline Alpha coefficient for the whole scale & 0,741 & 0,862 & 0,860 \\
\hline Scale average & 3,9631 & 3,2063 & 3,2009 \\
\hline
\end{tabular}

The 10-item career interest scale was developed by Riegel and Dallas (1998) and Kusluvan and Kusluvan (2000). Turkish adaptation of this scale is described in Duman et al. (2006). In our research it was seen that the scale was collected in two dimensions and $54 \%$ of the total variance was explained.

The reliability coefficient of the 10 -item career interest scale was reported as .92 (Kusluvan and Kusluvan, 2000: 265). In reliability analysis, it was decided to exclude two items ("I loathe changing my workplace" $(0,038)$ and "I do not think that I will make a career in a sector other than tourism" $(0,147))$. In the analysis made with 8 items, the multiple explanatory value $\left(\mathrm{R}^{2}\right)$ of an item was 0.243 and since the item-total correlation of this item was 0.435 , it was decided to be kept in the scale. The reliability coefficient of the remaining 8 items as a whole was 0.862 . The academic procrastination scale was composed of 19 items. This scale was adapted to Turkish by Çakıcı, 2003. In our research, a three-dimensional structure was 
identified and $61 \%$ of total variance was explained.

The reported reliability coefficient of the 19item academic procrastination scale was .92 (Çakıc1, 2003: 77). In the reliability analysis it was determined that multiple explanatory value $\left(\mathrm{R}^{2}\right)$ of four items (8. I leave studying boring lessons to the last minute $(0,278), 10$. While studying I often take a break to do something, to talk to someone, to drink tea or coffee etc. $(0,268), 13$. If I have prepared a study program for myself, I stick to it $(0,289) 15$.there are some courses I have failed just because I left studying for them to the last minute $(0,272))$ were too close although all of them are under 0,300 . It was also determined that total item correlation values of these 4 items were 0,391 , $0,388,0,396$ and 0,416 respectively and all being higher than, 250 they weren't excluded from the scale. The reliability coefficient of the scale as a whole was 0,860 .

\subsection{Respondents' profile}

Table 2 shows the percentages of the participants based on some demographic variables. $60 \%$ of the students are male and the associate and undergraduate students are almost half to half. $85 \%$ is under 23 years old. Two thirds of the participants are daytime education students. Those who chose their schools in the first row are approximately two thirds of the total participants. $50 \%$ has chosen the school in one of the first three choices. The average order of choice is 5,15 among 418 students (sd:5,814, min:1, max:30). For the 264 students who indicated their grade point averages the range is between 0.55 minimum and 3.97 maximum and the average is 2,3022 (sd:0,61127) in 4point grading system.

Table 2. Distribution of student according to demographic information (n:462)

\begin{tabular}{|c|c|c|c|c|c|}
\hline Demographics & $\mathrm{F}$ & $\%$ & Demographics & $\mathrm{f}$ & $\%$ \\
\hline Gender & & & Age & & \\
\hline Male & 273 & 59,1 & $17-20$ & 185 & 40,0 \\
\hline Female & 189 & 40,9 & $21-23$ & 215 & 46,5 \\
\hline Department & & & $24+$ & 62 & 13,4 \\
\hline Tourism Management. (Undergraduate) & 239 & $\% 51,7$ & \multirow{2}{*}{\multicolumn{3}{|c|}{$\begin{array}{l}\text { Rank of choice (n:418) } \\
\text { Avg.:5,15; sd.:5,814; Min:1; Max:30 }\end{array}$}} \\
\hline Tourism \& Hotel Management (Associate) & 223 & 48,3 & & & \\
\hline Grade & & & 1 & 146 & 31,6 \\
\hline 1 & 157 & 34,0 & $2-3$ & 89 & 19,3 \\
\hline 2 & 199 & 43,1 & $4-5$ & 59 & 12,8 \\
\hline 3 & 63 & 13,6 & $6-10$ & 59 & 12,8 \\
\hline 4 & 43 & 9,3 & $11-30$ & 65 & 14,1 \\
\hline \multicolumn{3}{|l|}{ Grade point average (n:264) } & Programme & & \\
\hline \multirow{2}{*}{$\begin{array}{l}\text { Avg.:2,3022; sd:0,61127 } \\
\text { Min:0,55; max: } 3,97\end{array}$} & & & Daytime education & 308 & 66,7 \\
\hline & & & Evening education & 154 & 33,3 \\
\hline
\end{tabular}

\subsection{Factor analyses of the scales}

The factor analysis applied to the long-term orientation scale which went down to 5 items after reliability analysis revealed a two-dimensional structure explaining $71 \%$ of the total variance. KMO sampling adequacy was determined as $71.0 \%$ in the analysis. The Bartlett's Test of Sphericity $\left(\chi^{2}: 573,554\right.$; s.d.: $\left.10 ; p<0.001\right)$ is also significant. This is also confirmed by the fact that the data set conforms to the factor analysis and the data shows a multivariate normal distribution. Accordingly, the first factor consisting of two items explains $35 \%$ of the total variance. In this factor, the importance of respect for the customs $(0,875)$ and the traditional values $(0,872)$ had been united. Therefore, the factor is named as traditionalism and both factors are major characteristics. The second factor consists of three items and explains $35 \%$ of the total variance. In this factor; giving up today's enjoyment for the benefit of the future $(0,859)$, hardworking for the future $(0,784)$ and persistence $(0,587)$ were united. Since the items indicate planning, the factor is named "planning". Here, giving up today's pleasure for the benefit of the future and hardworking grabs attention (load> 0.700 ). 
Table 3. Long term orientation factor analysis results

\begin{tabular}{|c|c|c|c|c|c|}
\hline & Load & Eigenvalue & E. Variance & Average & Alpha \\
\hline I.Traditionalism & & 1,782 & 35,648 & 4,1748 & 0,765 \\
\hline 1. Respect for tradition is important to me. & 875 & & & 4,2842 & \\
\hline 7. Traditional values are important for me. & 872 & & & 4,0654 & \\
\hline II.Planning & & 1,746 & 34,919 & 3,8219 & 0,682 \\
\hline $\begin{array}{l}\text { 6. I don't mind giving up today's fun for success } \\
\text { in the future. }\end{array}$ &, 859 & & & 3,5808 & \\
\hline 5.I work hard for success in the future. & 784 & & & 3,7137 & \\
\hline 8.Persistence is important to me. & 587 & & & 4,1714 & \\
\hline $\begin{array}{r}\text { Basic Components Analysis with } \\
\text { KMO Sampling Adequacy: \%71,0; } \\
\text { General Average: } \\
\text { Respond Categorie }\end{array}$ & $\begin{array}{l}\max \mathrm{R} \\
\text { ett's T } \\
31 ; \mathrm{Al} \\
\text { Totall }\end{array}$ & $\begin{array}{l}\text { on; Total V } \\
\text { f Sphericity } \\
\text { or the Whol } \\
\text { ree...,5: To }\end{array}$ & $\begin{array}{l}\text { ciance Explai } \\
\chi^{2}: 573,554 ; \\
\text { Scale: }, 741 \\
\text { lly Disagree }\end{array}$ & $\begin{array}{l}\text { : } \% 70,56 \\
\therefore 10 ; p<0\end{array}$ & \\
\hline
\end{tabular}

The career interest scale in tourism consisted of 10 items, but after the reliability analysis two items have been deleted and it was decreased to eight. In factor analysis conducted with eight items, two dimensions were identified, explaining $65 \%$ of the total variance. KMO sampling adequacy was $87 \%$. The Bartlett's Test of Sphericity $\left(\mathrm{x}^{2}: 1570,593\right.$; s.d.: $\left.28 ; \mathrm{p}<0.001\right)$ also confirms that the data set conforms to the factor analysis and that the data came from the multivariate normal distribution.

The first factor consists of five items and explains $36 \%$ of the total variance. In this factor; the belief that there is not much to gain from a career in tourism (0.788), not knowing what to do after graduation (0.775), not being able to work in tourism for many years $(0.744)$, not contemplating tourism career after graduation (0.707) and accepting tourism preference as a mistake $(0,699)$ were combined. When the items were examined, it refers to a non-tourism career and therefore the factor is called "Career Interest Other Than of Tourism". Although all of the items are major, the idea that there is not much to gain from a tourism career is predominant.

The second factor consists of three items describing career interest in tourism. In this factor; being interested in the job opportunities in tourism sector $(0,790)$, looking for a future in tourism $(0,785)$ and the talking on the job opportunities in tourism $(0,583)$ were united. Therefore, the factor is called "Career Interest in Tourism". The factor explains $28 \%$ of the total variance; being interested in the job opportunities in tourism sector and looking for a future in tourism are clearly predominant issues.

Table 4. Factor analysis results of career interest scale

\begin{tabular}{|c|c|c|c|c|c|}
\hline & Load & Eigenvalue & E. Variance & Average & Alpha \\
\hline I. Career Interest Other Than Tourism & & 2,908 & 36,346 & 3,2648 & 0,860 \\
\hline $\begin{array}{l}\text { 4. There is not much for me to gain from a } \\
\text { career in tourism }\end{array}$ & ,788 & & & 3,5326 & \\
\hline 3. I don't know what to do after graduation. & ,757 & & & 3,3638 & \\
\hline $\begin{array}{l}\text { 2. I can not work in tourism sector for many } \\
\text { years. }\end{array}$ & ,744 & & & 2,8957 & \\
\hline $\begin{array}{l}\text { 1. It is definite that I will not work in the } \\
\text { tourism industry after graduation }\end{array}$ & ,707 & & & 3,1277 & \\
\hline $\begin{array}{l}\text { 5. It was a big mistake to choose tourism as a } \\
\text { career path }\end{array}$ & ,699 & & & 3,4043 & \\
\hline II.Career Interest in Tourism & & 2,219 & 27,735 & 3,1087 & 0,668 \\
\hline $\begin{array}{l}\text { 7. I am interested in the job opportunities in } \\
\text { tourism sector. }\end{array}$ & ,790 & & & 3,3283 & \\
\hline $\begin{array}{l}\text { 6.I think my future is related with the future } \\
\text { of the tourism sector. }\end{array}$ & ,785 & & & 2,9934 & \\
\hline $\begin{array}{l}\text { 10. We usually talk about the job opportuni- } \\
\text { ties in tourism sector among friends. }\end{array}$ & ,583 & & & 3,0043 & \\
\hline \multicolumn{6}{|c|}{$\begin{array}{c}\text { Basic Components Analysis with Varimax Rotation; Total Variance Explained: \%64,781; } \\
\text { KMO Sampling Adequacy: \%87,1; Bartlett's Test of Sphericity: } \chi^{2}: 1570,593 ; \text { s.d.: } 28 ; p<0.001 \\
\text { General Average: } 3,2063 \text {; Alpha for the Whole Scale: } 0,862 \\
\text { Respond Categories:1: Totally Agree...,5: Totally Disagree }\end{array}$} \\
\hline
\end{tabular}


In the factor analysis applied to the 19-item academic procrastination scale, four items with a coorigin of less than 0.400 were removed in the first place (these are four of the five items with multiple RE values less than 0.300 ), then three more items under 0.500 were removed and the analysis was completed as such (Table 4). Thus, the lowest homogeneity was 0,498 . KMO value was $82.4 \%$; Bartlett's Test of Sphericity (p2: 1784,730; s.d.: 66; $\mathrm{p}<0.001$ ). Thus, it is understood that the data set is suitable for factor analysis and the data displays multivariate normal distribution.

The first factor consists of six items and explains $25 \%$ of the total variance. In this factor; items of leaving studying for important exams to the last day. $(0,727)$, leaving it to the last day to prepare for important courses $(0,726)$, thinking about other things to do while studying $(0,699)$, dealing with other jobs before the exams $(0,682)$, doing pleasant things instead of studying $(0,681)$ and not completing assignments for minor reasons $(0,604)$ were combined. Considering the items, it is understood that the preparation for the lessons or exams are being constantly postponed, and other tasks are taken instead. Thus, the factor is named "Procrastination". In this factor, leaving the preparations for the courses and exams to the last day is conspicuous.

The second factor, which consists of three items, explains $19 \%$ of the total variance. This factor was named "Punctuality" since the items constituting the factor are submitting assignments/projects on time $(0,818)$, completion of the assignments $(0,782)$ and completing them before the deadline $(0,746)$. All three are major items and submitting assignments and projects on time is noteworthy among them in this factor (load> 0.700).

Table 5. Factor analysis results of academic procrastination

\begin{tabular}{|c|c|c|c|c|c|}
\hline & Load & Eigenvalue & E. Variance & Average & Alpha \\
\hline I. Procrastination & & 3,035 & 25,295 & 3,1129 & 0,810 \\
\hline $\begin{array}{l}\text { 6. Even if I have important exams, I leave studying } \\
\text { for these exams to the last day. }\end{array}$ &, 727 & & & 3,1435 & \\
\hline $\begin{array}{l}\text { 14. I leave studying to the last day even for im- } \\
\text { portant courses. }\end{array}$ &, 726 & & & 3,2494 & \\
\hline $\begin{array}{l}\text { 5. Every time I start to study other things I need to } \\
\text { do come to my mind. }\end{array}$ & 699 & & & 2,7467 & \\
\hline $\begin{array}{l}\text { 12. Even if the exam date has already been an- } \\
\text { nounced, I would be dealing with other jobs that } \\
\text { have no priority when the exam day comes close. }\end{array}$ & ,682 & & & 3,1463 & \\
\hline 3. I quit studying early to do more pleasant things. &, 681 & & & 2,9055 & \\
\hline $\begin{array}{l}\text { 18. I leave my assignments / projects to the last day } \\
\text { with trivial reasons. }\end{array}$ & ,604 & & & 3,4859 & \\
\hline II.Punctuality & & 2,311 & 19,259 & 3,9414 & 0,747 \\
\hline 11. I submit my assignments/ projects on time. &, 818 & & & 4,0263 & \\
\hline $\begin{array}{l}\text { 16. I can not finish my assignments/projects on } \\
\text { time. }\end{array}$ & ,782 & & & 3,8848 & \\
\hline $\begin{array}{l}\text { 2. I complete my assignments / projects before the } \\
\text { deadline. }\end{array}$ &, 746 & & & 3,9132 & \\
\hline III.Being Hardworking & & 1,993 & 16,611 & 2,9098 & 0,510 \\
\hline 7. I attend the classes prepared. &, 815 & & & 2,7582 & \\
\hline $\begin{array}{l}\text { 9. I complete the reading assignments given for any } \\
\text { course before attending to the classes. }\end{array}$ &, 780 & & & 2,8434 & \\
\hline 1. I study to my lessons regularly. &, 661 & & & 3,1277 & \\
\hline \multicolumn{6}{|c|}{$\begin{array}{c}\text { Basic Components Analysis with Varimax Rotation; Total Variance Explained: \%61,164; } \\
\text { KMO Sampling Adequacy: \%82,4; Bartlett's Test of Sphericity: } \chi^{2}: 1784,730 ; \text { s.d.: 66; } p<0.001 \\
\text { General Average: } 3,2691 \text {; Alpha for the Whole Scale: } 0,823 \\
\text { Respond Categories:1: Totally Agree...,5: Totally Disagree }\end{array}$} \\
\hline
\end{tabular}


The last factor explaining $16.6 \%$ of the total variance consists of three items. In this factor with low reliability $(\alpha: 0,510)$; attending the classes prepared $(0,815)$, completing the given reading assignments before attending the classes $(0,780)$ and studying regularly $(0,661)$ were collected. Considering the items, this factor is called "Being Hardworking". Attending the classes prepared and completing the given reading assignments before attending the classes are of significant quality among the items.

Multiple regression analysis was performed to determine the effect of long-term orientation on career interest. It was determined that the model could be used to explain the career interest other than tourism $\left(\mathrm{F}_{2} ; 459: 10,039, \mathrm{p}<0,001\right)$. While the coefficient of traditionalism is insignificant, one unit increase in planning increases the career interest other than the tourism sector by 0.216 units.

Students who receive tourism education at university level may naturally be expected to continue their careers in tourism sector. Therefore, the following step regression analysis and mediation test were conducted by considering the "Career Interest in Tourism" dimension on career interest scale. It is understood that the career interest in

Table 6. Results of the regression analysis tourism is best explained by "planning" (F1; 460: 37,794; $p<0,001)$. This model explains the career interest in tourism by $7.4 \%$. It is ought to be accepted that this ratio is low. One unit increase in planning increases the career interest in tourism by 0.276 units. Thus, $\mathrm{H}_{1}$ is supported.

The analysis to determine which of the two dimensions of long-term orientation can explain the "being hardworking" factor which can be used to best explain the career interest in tourism, revealed that the model was significant $\left(\mathrm{F}_{1} ; 460: 72,072\right.$, $\mathrm{p}$ $<0,001)$. According to this, the best long-term orientation dimension explaining "hardwork" is "planning". A one-unit increase in planning increases being hardworking by 0.368 units and can explain $13.4 \%$ of the change in hardworking. It is understood that $\mathrm{H}_{2}$ hypothesis is supported.

The stepwise regression analysis for the effect of academic procrastination on career interest in tourism has shown that the model can be used in the prediction process $\left(\mathrm{F}_{1 ; 460} ; 460: 26,914, \mathrm{p}\right.$ $<0,001)$. He showed that the dimensions of hard work have a positive impact on career interest in tourism and a rise in hard work has led to an increase of 0.235 units on career interest in tourism. This model describes a low rate of $5.3 \%$ of the change in the dependent variable. Thus, $\mathrm{H}_{3}$ hypothesis is supported.

\begin{tabular}{|c|c|c|c|c|c|c|}
\hline \multirow[b]{2}{*}{ Models } & & \multicolumn{2}{|c|}{ Non-standardized coefficients } & $\begin{array}{l}\text { Standardized coeffi- } \\
\text { cients }\end{array}$ & \multirow[t]{2}{*}{$\mathrm{t}$} & \multirow{2}{*}{$\begin{array}{l}\text { Level of signifi- } \\
\text { cance }\end{array}$} \\
\hline & & $\mathrm{B}$ & Std. Error & Beta & & \\
\hline \multirow{3}{*}{ 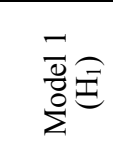 } & (Fixed) & 1,785 & ,220 & & 8,127 &, 000 \\
\hline & Planning & ,346 & ,056 & ,276 & 6,148 &, 000 \\
\hline & \multicolumn{6}{|c|}{$\begin{array}{l}\text { Dependent variable: Career Interest in Tourism } \\
\text { R: } 0,276 ; \mathrm{R}^{2}: 7,6 \% \text {; Adjusted } \mathrm{R}^{2}: 7,4 \% \text {; (for the Model) } \mathrm{F}_{1 ; 460}: 37,794, \mathrm{p}<0,001\end{array}$} \\
\hline \multirow{3}{*}{ 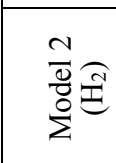 } & (Fixed) & 1,284 & ,195 & & 6,574 &, 000 \\
\hline & Planning & ,425 &, 050 & ,368 & 8,490 &, 000 \\
\hline & \multicolumn{6}{|c|}{$\begin{array}{l}\text { Dependent variable: Hardwork } \\
\text { R:0,368; } \mathrm{R}^{2}: 13,5 \% \text {; Adjusted R }: 13,4 \% \text {; (for the Model) } \mathrm{F}_{1 ; 460}: 72,072, \mathrm{p}<0,001\end{array}$} \\
\hline \multirow{3}{*}{ 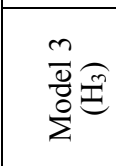 } & (Fixed) & 2,365 & , 150 & & 15,752 &, 000 \\
\hline & Hardwork & ,256 & ,049 & ,235 & 5,188 &, 000 \\
\hline & \multicolumn{6}{|c|}{$\begin{array}{l}\text { Dependent variable: Career Interest in Tourism } \\
\mathrm{R}: 0,235 ; \mathrm{R}^{2}: 5,5 \% \text {; Adjusted } \mathrm{R}^{2}: 5,3 \% \text {; (for the Model) } \mathrm{F}_{1 ; 460}: 26,914, \mathrm{p}<0,001\end{array}$} \\
\hline \multirow{4}{*}{ 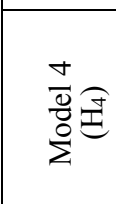 } & (Fixed) & 1,569 & ,227 & & 6,900 &, 000 \\
\hline & Planning & ,275 & ,060 & ,219 & 4,582 &, 000 \\
\hline & Hardwork & , 168 & ,052 & , 155 & 3,241 & ,001 \\
\hline & \multicolumn{6}{|c|}{$\begin{array}{l}\text { Dependent variable: Career Interest in Tourism } \\
\text { R: } 0,311 ; \mathrm{R}^{2}: 9,7 \% \text {; Adjusted } \mathrm{R}^{2}: 9,3 \% \text {; (for the Model) } \mathrm{F}_{2 ; 459}: 24,540, \mathrm{p}<0,001\end{array}$} \\
\hline
\end{tabular}


Planning among the long-term orientation scale and being hardworking among the academic procrastination scale are revealed to have a positive impact on career interest in tourism. With the addition of hardworking to the model, the $t$ value of the planning decreased from 6,148 ( $\mathrm{p}<0,0001)$ to 0,219 ( $\mathrm{p}<0,0001)$, but still remains significant. Therefore, it is clear that being hardworking is a partial mediator on the effect planning on career interest in tourism. Thus, the mediating hypothesis $\left(\mathrm{H}_{4}\right)$ is also supported. However, it should be noted that the last model can be used in explaining career interest in tourism only by $9.3 \%$ and this ratio is low.

The Sobel test was used to determine the significance of the partial mediation effect of being hardworking on the effect of planning over long-term orientation scale on career interest in tourism. The proposed formula for the test by Sobel (1982) is as follows, and the result is approximately equal to the value $Z$ (MacKinnot, Lockwood, Hoffman, West and Sheets, 2002: 85).

$$
\mathrm{Z}=\frac{\boldsymbol{a b}}{\sqrt{\boldsymbol{b}^{2}} \boldsymbol{S \boldsymbol { a } ^ { 2 } + \boldsymbol { a } ^ { 2 } \boldsymbol { S } \boldsymbol { b } ^ { 2 }}}=3,98943
$$

In the formula $a$ represents the non-standardized coefficient value (a: 0,346$)$ between the independent variable (planning) and the agent variable (career interest in tourism), whereas $S a$ represents the standard error value $(S a: 0,056)$ of this coefficient. In the formula, $b$ represents the non-standardized coefficient value ( $b: 0.256)$ between the mediator variable and the dependent variable (career interest in tourism), and $S b$ represents the standard error value ( $S b: 0.049)$ of this coefficient. $Z$ value was calculated as 3,98943 . Since the standard $Z$ value of $\alpha: 0.05$ was greater than 1.96 , it was concluded that the mediating effect was significant $(\mathrm{p}<0.001)$.

\section{Conclusion}

In this study, it has been tried to determine the effect of long-term orientations of tourism and associate degree students on their intention to pursue a career and to determine whether academic postponement has an intermediary role in career intentions in the long term. According to the results of the study, the hypothesis that long-term orientation of university students receiving tourism education affects the intention to make a career in tourism sector is supported. Dinçer, Akova and Kaya (2013) coincide with the research which determined that the students studying at the associate level aim to reach top positions in the tourism sector in the long term. The dimension that best describes industriousness from the dimensions of academic procrastination is plaint from long-term orientation dimensions. Diligence size has been found to increase career intention in tourism. This increase supports the hypothesis that university students receiving tourism education affect the long-term orientation intention. The hypothesis that academic procrastination affects the academic procrastination behaviors and career intention also seen with the findings is obtained. It is clear that long term orientation positively affects the career intention of tourism in the tourism sector. Therefore, it appears that the effect of planning on career intention in tourism is a partial instrument of diligence. Thus, the hypothesis that academic procrastination plays a mediating role in the relationship between long-term orientation and career intention on university students receiving tourism education is supported. This finding coincides with the findings of the study conducted by Jadidi, Mohammadkhani and Tajrishi (2011), who determined that the tourism students procrastinates because they wish to be perfect for the academic goals.

According to the findings, it is observed that the planning, according to the long-term orientations of the students receiving tourism education, has an impact on career intention both in tourism and outside of tourism. The effectiveness of being planned in daily life is also seen with the findings obtained. In addition, the positive effect of diligence on career intention in tourism will be a gain on behalf of the tourism sector in terms of the positive effect of the students receiving tourism education on the perspective of tourism sector.

The findings of our study can give remarkable information about career interests of the tourism students, their long-term orientation and tendency towards academic procrastination primarily to university administrators and academicians who give education at associate and bachelor's degree and then to the owners and managers of tourism enterprises in the tourism sector. At the same time, this study can make significant contributions to the researchers by enriching the literature since there has not been any study in this direction regarding the students who have previously received tourism education. 
The scope of this study limited to the students of Mersin University and Selcuk University can be expanded and applied in the other cities of Turkey. In addition, expending the scope of this study to the other countries later on might be important in terms of comparison.

\section{References}

Baltaci, F., Üngüren, E., Avsallı, H., \& Demirel, H. N. (2012). Turizm Eğitimi Alan Öğrencilerin Eğitim Memnuniyetlerinin ve Geleceğe Yönelik Bakış Açılarının Belirlemesine Yönelik Bir Araştırma. Uluslararası Alanya İşletme Fakültesi Dergisi, 4(1).

Bearden, W. O., Money, R. B., \& Nevins, J. L. (2006). A measure of long-term orientation: Development and validation. Journal of the Academy of Marketing Science, 34, 456-467.

Blunt, A., \& Pychyl, T. A. (1998). Volitional action and inaction in the lives of undergraduate students: State orientation, procrastination and proneness to boredom. Personality and Individual Differences, 24(6), 837-846.

Bonner, D. (1972). Evaluating the effects of using upperclassmen trained in group dynamics to lead small process oriented freshman orientation groups. Washington, DC: National Center for Educational Research and Development (DHEW/OE), Regional Research Program.

Brigham, K. H., Lumpkin, G. T., Payne, G. T., \& Zachary, M. A. (2014). Researching long-term orientation: A validation study and recommendations for future research. Family Business Review, 27(1), 72-88

Çiğdem Sofyalıoğlu, Rabia Aktaş, "Kültürel Farklılıkların Uluslararası İşletmelere Etkisi”, Celal Bayar Üniversitesi İ.İ.B.F. Yönetim ve Ekonomi Dergisi, 7/1, 2001, s.91.

Dinçer, F. İ., Akova, O., \& Kaya, F. (2013). Meslek Yüksekokulu Turizm ve Otel İşletmeciliği Programı Öğrencilerinin Kariyer Planlaması Üzerine Bir Araştırma: İstanbul Üniversitesi ve Gümüşhane Üniversitesi Örneği. Elektronik Mesleki Gelişim Ve Araştırmalar Dergisi, 1(2), 42-56.

Duman, T., Tepeci, M., \& Unur, K. (2006). Mersin'de Yükseköğretim ve Orta Öğretim Düzeyinde Turizm Eğitimi Almakta Olan Öğrencilerin Sektörün Çalışma Koşullarını Algılamaları ve Sektörde Çalışma İsteklerinin Karşılaştırmalı Analizi. Anatolia: Turizm Araştırmaları Dergisi,17(1), 51-69.

Ermurat Mustafa, A. (2013). Marka Gücü ve Rol Performansının Perakendeci Memnuniyetine, Bağımlılığına
Ve Uzun Dönem Yönelimine Etkisi. Yayımlanmamış doktora tezi, Gebze Yüksek Teknoloji Enstitüsü, Gebze.

Ferrari, J. R. (1991). Compulsive procrastination: Some selfreported characteristics. Psychological reports, 68(2), 455-458.

Ferrari, J. R., Parker, J. T., \& Ware, C. B. (1992). Academic Procrastination: Personality Correlates with MyersBriggs Types, Self-Efficacy, and Academic Locus of Control. Journal of Social Behavior and Personality, 7(3), 495.

Ferrari, J. R., Özer, B. U., \& Demir, A. (2009). Chronic procrastination among Turkish adults: Exploring decisional, avoidant, and arousal styles. The Journal of social psychology, 149(3), 402-408.

Gass, M. A., Garvey, D. E., \& Sugerman, D. A. (2003). The long-term effects of a first-year student wilderness orientation program. Journal of Experiential Education, 26(1), 34-40.

Geert Hofstede, (1980). Motivation, Leadership and Organization: Do American Theories Apply Abroad?, Organizational Dynamics, Summer

Güzel, T., Akdağ, G., Güler, O., \& Şener, S. (2014). Turizm Eğitimi Alan Öğrencilerin Turizmde Kariyer Algılamaları: Çanakkale, Mersin ve Kıbrıs' ta Bir Araştırma. 3. Doğu Akdeniz Sempozyumu, ss. 176-187, 18 Nisan 2014, Mersin

Gwinner, K. P., Bitner, M. J., Brown, S. W., \& Kumar, A. (2005). Service customization through employee adaptiveness. Journal of Service Research, 8(2), 131-148.

Hofstede, G., \& Minkov, M. (2010). Long-versus short-term orientation: new perspectives. Asia Pacific Business Review, 16(4), 493-504.

Howell, A. J., \& Watson, D. C. (2007). Procrastination: Associations with achievement goal orientation and learning strategies. Personality and Individual Differences, 43(1), 167-178.

Jadidi, F., Mohammadkhani, S., \& Tajrishi, K. Z. (2011). Perfectionism and academic procrastination. ProcediaSocial and Behavioral Sciences, 30, 534-537.

Klassen, R. M., Krawchuk, L. L., \& Rajani, S. (2008). Academic procrastination of undergraduates: Low self-efficacy to self-regulate predicts higher levels of procrastination. Contemporary Educational Psychology, 33(4), 915-931.

Kozak, M. A., \& Kızılırmak, İ. (2001). Türkiye'de meslek yüksekokulu turizm-otelcilik programı öğrencilerinin turizm sektörüne yönelik tutumlarının demografik 
değişkenlere göre değişimi: Anadolu, Akdeniz ve Karadeniz Teknik Üniversitesi öğrencileri üzerine bir uygulama. Anatolia: Turizm Araştırmaları Dergisi, 12(1), 916.

Kusluvan, S., ve Kusluvan, Z. (2000). Perceptions and attitudes of undergraduate tourism students towards working in the tourism industry in Turkey, Tourism Management, 21(3), 251-269.

Lay, C. H. (1986). At last, my research article on procrastination. Journal of research in personality, 20(4), 474495.

Lumpkin, G. T., Brigham, K. H., \& Moss, T. W. (2010). Long-term orientation: Implications for the entrepreneurial orientation and performance of family businesses. Entrepreneurship and Regional Development, 22(3-4), 241-264.

Morkoç, D, Doğan, M . (2015). Meslek Yüksekokulu Mezunu Çalışanların Mesleki Eğitime Yönelik Görüşleri: Çanakkale Onsekiz Mart Üniversitesi Örneği.

Nevins, J. L., Bearden, W. O., Money, R. B. (2007). Ethical Values and Long Term Orientation. Journal of Business Ethics, 71, 261-274.

Onwuegbuzie, A. J. (2004). Academic procrastination and statistics anxiety. Assessment \& Evaluation in Higher Education, 29(1), 3-19.

Öğüt, A. ve Kocabacak A. (2008). Küreselleşme Sürecinde Türk İş Kültüründe Yaşanan Dönüşümün Boyutları, Türkiyat Araştırmaları Dergisi, 23, 145-170.

Özer, A., \& Altun, E. (2011). Üniversite öğrencilerinin akademik erteleme nedenleri. Mehmet Akif Ersoy Üniversitesi Eğitim Fakültesi Dergisi, 1(21), 45-72.
Richardson, S. (2009). Undergraduates' perceptions of tourism and hospitality as a career choice. International Journal of Hospitality Management, 28(3), 382-388.

Roney, S. A., ve Öztin, P. (2007). Career perceptions of undergraduate tourism students: A case study in Turkey, Journal of Hospitality, Leisure, Sport and Tourism Education, 6(1), 4-17.

Rothblum, E. D., Solomon, L. J., and Murakami, J. (1986). Affective, cognitive, and behavioral differences between high and low procrastinators. Journal of Counseling Psychology, 33, 387-394.

Sax, L. J., Astin, A. W., \& Avalos, J. (1999). Long-term effects of volunteerism during the undergraduate years. The review of higher education, 22(2), 187-202.

Solomon, L. J. ve Rothblum, E. D. (1984). Academic Procrastination: Frequency and Cognitive-Behavioral Correlates. Journal of Counseling Psychology, 31, 503-509.

Sümer, C. (2016, 11 Nisan). İnsan Kaynaklanı Yönetimi Olarak Örgütsel Kariyer Planlama ve Geliştirme, www.sosyalhizmetleruzmani,org/kariyerplanlama.htm.

Tabak, A., Basım, N., Tatar, İ. ve Çetin, F. (2010). İzlenim yönetimi taktiklerinde beş faktör kişilik özelliklerinin rolü: Savunma sanayiinde bir araştırma. Ege Akademik Bakış / Ege Academic Review, 10 (2), 539-557.

Türkay, O., \& Solmaz, S. A. (2011). Liderlik yeteneği ve kariyer değerlerinin turizmde kariyer yapma isteği üzerindeki etkileri. Ticaret ve Turizm Eğitim Fakültesi Dergisi, 1(2), 46-71.

Yıldız, Banu S. (2013), "Lisans Düzeyinde Turizm Eğitimi Alan Öğrencilerin Sektörde Çalışmaya Yönelik Bakış Açıları" Erciyes Üniversitesi 14.Ulusal Turizm Kongresi,595-614, 05-08 Aralık, Kayseri. 